ORIGINAL ARTICLE

\title{
THE RELATIONSHIP OF NUTRITIONAL STATUS TO URIC ACID LEVEL IN COMMUNITY OF PONDOK PESANTREN AL-HIDAYAH, NGAWI
}

\author{
,Marselli Widya Lestari ${ }^{1}$, Tri Wahyuni Bintarti ${ }^{2}$. \\ ${ }^{1,2}$ Fakultas Kedokteran Universitas Nahdlatul Ulama Surabaya, Indonesia \\ *Correspondent Author: marselli@unusa.ac.id
}

\section{ARTICLE INFO}

Article history:

Received 23 January 2019

Received in revised form

February 2019

Accepted 4 February 2019

\section{Keywords:}

Nutritional status,

Uric acid,

Gout risk factor.

\begin{abstract}
Gout or Gouty Arthritis is a degenerative disease. Gouty arthritis is a clinical syndrome that is caused by deposition of purine crystals in the tissues, due to levels of uric acid (hyperuricemia) in the extracellular fluid that passes through saturation. The etiology of gout arthritis included age, sex, history of medication, obesity, consumption of purine and alcohol. Aging is an important risk factor for men and women. This study uses an analytical-descriptive approach with cross-sectional design. This study was conducted to obtain a relationship between nutritional status and uric acid levels in the community in the area of Al-Hidayah Islamic Boarding School, Ngawi. This research was conducted in Majasem Village, Kendal District, Ngawi Regency, starting from 7 June - 31 August 2018. The results showed that there was a relationship between nutritional status and uric acid levels in the community in the area of Al-Hidayah Islamic Boarding School, Ngawi ( $\mathrm{p}=0,008)$. Suggestions for further research are bivariate analysis based on gender, knowledge and attitude to response to diet so that other factors that influence can be seen clearly.
\end{abstract}

\section{PENDAHULUAN}

Life Expansion of Life Expectancy (UHH) is one indicator of the success of development in the health and welfare of the population. This has an impact on the increasing number of elderly people (elderly). Based on the 2013 United Nations report, UHH in 2013 was 71 years (with a percentage of the elderly population reaching 12\%) (United Nations, 2013). The phenomenon of an increase in the number of elderly population is caused by a decrease in population fertility, improvement in health status due to technological advances and medical research, improvement in nutritional status which is marked by an increase in cases of obesity in elderly than underweight, to epidemiological transition from infectious diseases to degenerative diseases ( Fatmah 2010).
Risk factors that are very closely related to this degenerative disease are lifestyle, including excess weight (obesity). National central obesity prevalence is $18.8 \%$, where there is still atendency to remain high when entering the elderly at $23.1 \%$ (age group 55-64), 18.9\% (age group 65-74) and $15.8 \%$ (group 75 years and over) (WHO, 2012). The Indonesian Ministry of Health (2012) explains that excess nutrition in the elderly is usually associated with lifestyle and excessive consumption patterns from a young age even since children. In addition, the decreased metabolic process in the elderly if it is not balanced with an increase in physical activity or a decrease in the amount of food causes excess calories to be converted into fat causing obesity. This shows that overweight and obesity must also remain aconcern 
because it can spur the onset of degenerative diseases, especially gout.

Gout or Gouty Arthritis is a degenerative disease. Gouty arthritis is a clinical syndrome that is caused by deposition of purine crystals in tissues, due to levels of uric acid (hyperuricemia) in the extracellular fluid that passes through saturation (Tehupeiory, 2012). The etiology of gout arthritis included age, sex, history of medication, obesity, consumption of purine and alcohol. Aging is an important risk factor for men and women. This is likely due to many factors (Tehupeiory, 2012). Gout Arthritis (Gout) is a disease that is commonly found in men between 30-40 years of age, whereas in women aged 55-70 years, the incidence of women is rare except after menopause (Tjokroprawiro, 2007 in Lumunon, 2015). In Indonesia, Gout arthritis ranks second after osteoarthritis (Dalimartha, 2008), the prevalence in Indonesia alone is estimated at 1.6-13.6 / 100,000 people, this prevalence increases with age (Tjokroprawiro, 2007).

Kendal sub-district area is a sub-district located in Ngawi district, East Java. Kendal subdistrict area is $84.56 \mathrm{~km} 2$ with a population in 2016 of 44,376 people. Population of Kendal subdistrict based on age is controlled by the age range of 4549 years, while the age above 60 years is 7,539 people (BPS Ngawi, 2017). With this data, the population of Kendal, Ngawi, is the age distribution of the population (old adults and elderly) is quite a lot so it is prone to degenerative diseases (gout).

Based on the description in the background of the problem above provides the basis for researchers to formulate the research questions as follows: What is the relationship between nutritional status and uric acid levels in the community in the Al-Hidayah Islamic Boarding School, Ngawi?.

\section{METHODS}

This study uses an analytical-descriptive approach with cross-sectional design. This study was conducted to obtain a relationship between nutritional status and uric acid levels in the community in the area of Al-Hidayah Islamic Boarding School, Ngawi. This research was conducted in Majasem Village, Kendal District, Ngawi Regency, starting from 7 June - 31 August 2018. Sampling done by accidental sampling method. With this method the researcher will record every citizen who came / met when the research took place. If the inclusion criteria are included, the residents are entered into the study. The data will be processed with SPSS.17, univariate analysis to see the proportion between nutritional status and uric acid levels and presented in the frequency distribution table. Furthermore, the data was processed with bivariate regression correlation analysis to determine the relationship between nutritional status and uric acid levels and presented with tables.

\section{RESULTS AND DISCUSSION}

The study was conducted cross-sectionally at Al-Hidayah Islamic Boarding School, Kendal, Ngawi on June 24, 2018 at 09.00. Characteristics of respondents can be seen in table 4.1. Respondents who attended were mostly female, namely $64.4 \%$. The average respondent present was the elderly (mean $=49$ ) with a dominance of $42.2 \%$ of the age group 26-45. In the second place as many as $31.1 \%$ are the age group 56-65. The characteristics based on the latest education are dominated by elementary school graduates, namely 21 people with a percentage of $46.7 \%$. In line with his latest education, almost $50 \%$ of livelihoods are farmers. 
Table 4.1. Karakteristik Responden

\begin{tabular}{|c|c|c|c|}
\hline No & Karakteristik Responden & Frekuensi $(n=45)$ & Persentase \\
\hline \multirow[t]{3}{*}{1} & Jenis Kelamin & & \\
\hline & Perempuan & 29 & 64.4 \\
\hline & Laki-laki & 16 & 35.6 \\
\hline \multirow[t]{6}{*}{2} & Usia & & \\
\hline & $17-25$ & 3 & 6.7 \\
\hline & $26-45$ & 19 & 42.2 \\
\hline & $46-55$ & 3 & 6.7 \\
\hline & $56-65$ & 14 & 31.1 \\
\hline & $>65$ & 6 & 13.3 \\
\hline \multirow[t]{7}{*}{3} & Pendidikan Terakhir & & \\
\hline & $\mathrm{S} 1$ & 9 & 20 \\
\hline & $\mathrm{S} 2$ & 1 & 2.2 \\
\hline & SD & 21 & 46.7 \\
\hline & SMA & 3 & 6.7 \\
\hline & SMP & 5 & 11.1 \\
\hline & Tidak Sekolah & 6 & 13.3 \\
\hline \multirow[t]{10}{*}{4} & Pekerjaan & & \\
\hline & Buruh & 1 & 2.2 \\
\hline & Guru & 7 & 15.6 \\
\hline & IRT & 4 & 8.9 \\
\hline & Mahasiswa & 1 & 2.2 \\
\hline & Pelajar & 1 & 2.2 \\
\hline & Petani & 22 & 48.9 \\
\hline & Swasta & 6 & 13.3 \\
\hline & Wiraswasta & 2 & 4.4 \\
\hline & Tidak Bekerja & 1 & 2.2 \\
\hline
\end{tabular}

In Univariate Nutritional Status analysis (table 4.2) only $35.6 \%$ had normal BMI. 55.6\% have nutritional status above normal, 7 of them are overweight and 40 are obese. This proportion corresponds to the age distribution of many respondents from the 56-65 age group. According to WHO (2012), national obesity prevalence at the national level is $18.8 \%$, where there is still a tendency to remain high when entering the elderly at $23.1 \%$ (age group 55-64), $18.9 \%$ (age group 6574) and $15.8 \%$ (group 75 years and over).
Tabel 4.2 Univariat Satus Gizi berdasarkan Klasifikasi IMT

\begin{tabular}{llrr}
\hline \hline & Klasifikasi & \multicolumn{2}{c}{ Frekuensi } \\
IMT & $(\mathbf{n = 4 5 )}$ & Persentase \\
\hline \hline 1 & Underweigth & 4 & 8.9 \\
2 & Normal & 16 & 35.6 \\
3 & Overweight & 7 & 15.6 \\
4 & Obese & 18 & 40.0 \\
\hline & Total & 45 & 100.0 \\
\hline \hline
\end{tabular}


Tabel 4.3 Univariat Kadar Asam Urat

\begin{tabular}{llrr}
\hline \hline & $\begin{array}{c}\text { Kadar Asam } \\
\text { Urat }\end{array}$ & $\begin{array}{c}\text { Frekuensi } \\
(\mathbf{n = 4 5})\end{array}$ & $\begin{array}{c}\text { Persenta } \\
\text { se }\end{array}$ \\
\hline \hline 1 & Normal & 36 & 80.0 \\
2 & Tinggi & 9 & 20.0 \\
\hline & Total & 45 & 100.0 \\
\hline \hline
\end{tabular}

More weight and obesity can trigger degenerative diseases, especially gout. However, in the univariate analysis of uric acid levels (table 4.3) it was seen at a glance that respondents who had high uric acid levels were only 9 people or $20 \%$ of the total while the other $80 \%$ were normal.

The results of research on nutritional status and uric acid levels of 45 respondents showed that respondents with normal nutritional status and underweight were safe from high levels of uric acid (table 4.4). While respondents with overweight nutritional status had 1 to 7 people, with high uric acid levels. This figure is increased in Obese IMT (> $25 \mathrm{~kg} / \mathrm{m} 2$ ) that is $8 / 18$ or $44 \%$ have high uric acid levels. The data was reprocessed using the Chi-square calculation (table 4.5) and obtained a significance of $\mathrm{p}=0.008$ which meant that there was a relationship between nutritional status and uric acid levels.

This has been conveyed in Budiono's research (2016) which states that the proportion of high levels of uric acid increases in respondents with high BMI. Likewise explained in the study by Lumunon (2015) in Manado, who took samples from elderly poly, that in the study there was a relationship between nutritional status and gout arthritis in the elderly in the work area of Manado Wawonasa Health Center. Factors that cause gouty arthritis proposed by Indriawan, 2009, one of them is diet, intake that enters the body also affects the level of uric acid in the blood. In this study also dominated by women $(64.4 \%)$ so that a little more influence on the results of the study. The amount of food high in purine consumed will increase the risk of gout in elderly women who in fact have decreased immunity due to estrogen which is no longer produced and decreased metabolic power increases the risk of gout according to theory (Sylvia, 2006).

Tabel 4.4 Crosstabulation antara Klasifikasi IMT dan Kadar Asam Urat

\begin{tabular}{clrrr}
\hline \hline & & \multicolumn{2}{c}{ Kadar Asam Urat } & \\
& & Normal & Tinggi & Total \\
\hline Klasifikasi IMT & Underweigth & 4 & 0 & 4 \\
& Normal & 16 & 0 & 16 \\
& Overweight & 6 & 1 & 7 \\
& Obese & 10 & 8 & 18 \\
\hline & Total & 36 & 9 & 45 \\
\hline
\end{tabular}

Tabel 4.5 Chi-Square Tests

\begin{tabular}{|c|c|c|c|c|c|c|c|c|}
\hline \multirow[b]{3}{*}{ Value } & \multirow[b]{3}{*}{ df } & \multirow{3}{*}{$\begin{array}{l}\text { Asymp. } \\
\text { Sig. (2- } \\
\text { sided) }\end{array}$} & \multicolumn{3}{|c|}{$\begin{array}{l}\text { Monte Carlo Sig. (2- } \\
\text { sided) }\end{array}$} & \multicolumn{3}{|c|}{$\begin{array}{l}\text { Monte Carlo Sig. (1- } \\
\text { sided) }\end{array}$} \\
\hline & & & & $\begin{array}{r}95 \\
\text { Conf } \\
\text { Inte } \\
\end{array}$ & $\begin{array}{l}\% \\
\text { dence } \\
\text { cval }\end{array}$ & & $\begin{array}{r}93 \\
\text { Conf } \\
\text { Int } \\
\end{array}$ & $\begin{array}{l}\% \% \\
\text { dence } \\
\text { rval }\end{array}$ \\
\hline & & & Sig. & $\begin{array}{l}\text { Lower } \\
\text { Bound }\end{array}$ & $\begin{array}{l}\text { Upper } \\
\text { Bound }\end{array}$ & Sig. & $\begin{array}{l}\text { Lower } \\
\text { Bound }\end{array}$ & $\begin{array}{l}\text { Upper } \\
\text { Bound }\end{array}$ \\
\hline
\end{tabular}




\begin{tabular}{|c|c|c|c|c|c|c|c|c|c|}
\hline $\begin{array}{l}\text { Pearson } \\
\text { Chi-Square }\end{array}$ & $11.865^{\mathrm{a}}$ & 3 & 0.008 & $.010^{\mathrm{b}}$ & 0.004 & 0.016 & & & \\
\hline $\begin{array}{l}\text { Likelihood } \\
\text { Ratio }\end{array}$ & 14.564 & 3 & 0.002 & $.005^{\mathrm{b}}$ & 0.001 & 0.009 & & & \\
\hline $\begin{array}{l}\text { Fisher's } \\
\text { Exact Test }\end{array}$ & 10.736 & & & $.013^{\mathrm{b}}$ & 0.006 & 0.02 & & & \\
\hline $\begin{array}{l}\text { Linear-by- } \\
\text { Linear } \\
\text { Association }\end{array}$ & $10.513^{\mathrm{c}}$ & 1 & 0.001 & $.001^{\mathrm{b}}$ & 0 & 0.003 & $.000^{\mathrm{b}}$ & 0 & 0.003 \\
\hline $\begin{array}{l}\mathrm{N} \text { of Valid } \\
\text { Cases }\end{array}$ & 45 & & & & & & & & \\
\hline
\end{tabular}

a. 5 cells $(62,5 \%)$ have expected count less than 5. The minimum expected count is, 80 .

b. Based on 1000 sampled tables with starting seed 926214481.

c. The standardized statistic is 3,242 .

\section{CONFLICTS OF INTEREST}

he author stated there is no conflict of interest.

\section{DAFTAR PUSTAKA}

1. Badan Pusat Statistik Kabupaten Ngawi. 2017.Kabupaten Ngawi Dalam Angka 2017: Katalog BPS 1102001.3521.

2. Badan Pusat Statistik Kabupaten Ngawi. 2017.Kecamatan Kendal Dalam Angka 2017: Katalog BPS 1102001.3521.

3. Badan Pusat Statistik. (2013). Statistik Penduduk Lanjut Usia 2013. Jakarta: Badan Pusat Statistik.

4. Carter, M.A 2006. Buku Ajar Patofisiologi. EGC 206-237. Jakarta.

5. Departemen Kesehatan. (2007). Riset Kesehatan Dasar (Prevalensi Obesitas Sentral Diatas Umur 15 Tahun). Diperoleh dari: http://www.litbang.depkes.go.id.[Diakses: 8 Agustus 2015].

6. FAO/WHO/UNU. (2001). "Human Energy Requirements." WHO Technical ReportSeries, no. 724. Geneva: World Health Organization.

7. Fatmah (2010). Gizi Usia Lanjut. Jakarta: Penerbit Erlangga.
8. Gibson RS. (2005). "Principles Of Nutritional Assessment. $2^{\text {nd }}$ ed." New York: Oxford University Press.

9. Hardinsyah, Hadi Riyadidan Victor Napitupulu. (2012). Kecukupan Energi, Protein, Lemak dan Karbohidrat. Bogor: Departemen Gizi FEMA IPB.

10. KementrianKesehatanRepublik Indonesia. (2012). PedomanPelayananGiziLanjutUsia Jakarta: KementrianKesehatan RI.

11. Nasrul, E dan Sofitri. 2012. Hiperurisemia pada Pra Diabetes. Jurnal kesehatan Andalas 1(2). Diakses : pada tanggal 24 april 2016. http://jurnal.fk.unand.ac.id.

12. Rau E, Jeffrey O, Vantje K. 2015. Perbandingan Kadar Asam Urat pada Subyek Obes dan Non-Obese di Fakultas Kedokteran Universitas Sam Ratulangi Manado. Jurnal eClinic (eCl). Diakses : pada tanggal 24 juli 2016.

http://ejournal.unsrat.ac.id/index/php/eclinic/ar ticle/view/8436/8014.

13. Setiani, Yuli. (2011). Hubungan Antara Status Gizi Dan Stres Dengan Kemampuan Activity Daily of Living pada Lanjut Usia di Wilayah Kerja Posyandu Lansia Puskesmas Sumbersari Kabupaten Jember.

14. Singh V, Gomez YV and Swamy SG. 2010. Approach to A Case Of Hyperuricemia. Ind $\mathrm{J}$ Aerospace Med 54 (1), 2010.

15. Tehupeiory, ES 2006, Artritis Gout dalam Buku AjarIlmu Penyakit Dalam, FKUI, Jakarta pp. 1208-1210. 
